\title{
Themes, Links and Public Forums: Developing Student Art Criticism Research Projects through Blogs
}

\author{
Stephanie Danker ${ }^{1}$, Karin Tollefson-Hall ${ }^{2}$, and Allyson Newman ${ }^{3}$ \\ Abstract: Blogs can be a useful tool for student research and reflection in a non- \\ traditional art criticism class. Implementing student created blogs proved \\ successful for keeping track of student progress on a semester-long research \\ project, assisting students to make connections between their research and the \\ course content, and incorporating student-generated materials into class \\ seminars. Surveys gathered at the end of the course demonstrated student \\ learning and level of satisfaction with the use of the blog as a course requirement.
}

Keywords: student research, reflection, themes, contemporary art criticism, assessment, collaborative.

Emerging in 2000 as tools to compose online entries on topics of personal interest (Lee \& Young, 2010), blogs can be effective for gathering and presenting student research (Bruff, 2011; Stiler \& Philleo, 2003). Blogs serve as visual records of dialogue, can be accessed chronologically or by topic, and content can be referred to in future online conversations (Overby, 2009). Blogs are meant to be frequently updated and invite social participation from readers. Luehmann and MacBride (2008) identified six distinct classroom blogging practices used by teachers and their students: (a) sharing resources; (b) responding to teacher prompts; (c) recording lessons' highlights; (c) posting learning challenges; (e) reflecting on what was learned; and (f) engaging in online conversations.

The use of blogs in pre-service coursework can aid teacher candidates in their abilities to reflect and provide constructive comments related to teaching (Buffington, 2008; HernandezRamos, 2004; Miller \& Williams, 2013; Rinke, Stebick, Schaefer, \& Gaffney, 2009; Wood, 2012). In a study of blogging with undergraduate pre-service students, Teclehaimanot and KahlePiasecki (2010) found that students reacted positively towards blogs for reflection on course material and contribution to learning. For our art criticism course, we prompted students to use blogs for research and reflection on big ideas and contemporary art images. In addition to our voices as co-instructors, reflections are included from one art criticism student.

\section{Art Criticism Course Design}

Methods of Art Criticism is a required course for art education students at James Madison University but is also open to studio art majors. Moving from a more traditional art criticism course design to include student blogs required a shift in student work, from personal to public.

\footnotetext{
1 Department of Art, Miami University, 400 S. Patterson Ave., Oxford, OH, dankers@miamioh.edu

${ }^{2}$ School of Art, Design and Art History, James Madison University, 820 S. Main St., Harrisonburg, VA 22807, tollefkl@jmu.edu

${ }^{3}$ MFA Candidate, Maine College of Art, 522 Congress St., Portland, ME, 04101, tidaleclipse@gmail.com
} 
In the traditional course, students learned about art criticism through Barrett's text, Why is That Art? (2012), class discussion, guided application, gallery visits, and a research paper. We valued the course text, student research of contemporary artists and themes, and the final presentations.

The use of blogs as research and reporting sites allowed students to share their research and resulting project with the class, instructors, and public. Educating students about writing and posting images in a public forum was important. Guidelines for writing were created and distributed that explained expectations for appropriate public writing. A university librarian met with the class to explain copyright laws, fair use images, and crediting sources for Internet images.

Integrating blogs into the course meant posts related to individual research were assigned weekly. Blog assignments included posting images of artworks chosen for the final project (with active links), background research on artists, and brief writing assignments connecting research to the course text.

Previously, the final research project was completed as a written paper and class presentation. We wanted students to connect the study of art criticism to their personal art making and future teaching. To do so, options for the final project became: 1) a formal research paper, 2) three original artworks inspired by research on their chosen artists and theme, or 3) a lesson plan incorporating the artists and theme researched.

As co-instructors, incorporating blogs presented cause for dividing teaching tasks. One instructor handled communications with students about the blog, monitored content and graded blog assignments. The other instructor led discussions and application of the text in the classroom and graded reading assignments. Defining our roles as instructors provided consistency for students to know which instructor to contact with questions about assignments and grading.

\section{Student Blogs}

Since we wanted the blogs to document ongoing research, each student created a blog. We did not assume that students had used or created one prior to our class. Directions for creating the blog and links to video tutorials were provided to students online. Also, a live demonstration assisted students in developing their sites. In order for students and instructors to have easy access to all of the blogs, each student's blog was linked to the main class website.

For all blog assignments, specific requirements were given for grading purposes. Miller and Williams (2013) provide examples of protocols for student blogs and assessment rubrics. Due dates for posting assignments included not only the day, but also the hour the post was to appear. Links posted were required to be active and proper citations of images and research were mandatory.

\section{Allyson's Student Perspective}

When I learned I would be creating a blog for this class I was slightly overwhelmed and nervous at the aspect of the assignment. I had never created a blog and, embarrassingly enough, had never read a blog before. As the semester progressed and I gained more experience utilizing the blog for assignments, I became more comfortable with blogs.

My initial frustration had more to do with narrowing down a topic of interest. I wanted to blog about something that would maintain my interest throughout the semester and evolve along 
with the research. I had some technical difficulties with the blog due to Internet and formatting issues. At first I was a bit nervous about the public aspect of using a blog. However, I quickly became accustomed to this as the assignment progressed. I was not concerned about the research itself being public, merely posting my actual thoughts and opinions publicly.

The most beneficial thing about this blog was simply the experience of the blog itself. Incorporating blogs into the research process made this assignment different by creating an air of ease and streamlining the assignment. The use of the blog increased my practice of art criticism by providing a venue to analyze artists and their works in a public forum.

Since its creation, I have continued to utilize the blog in other classes as well as a venue to post images and statements in regard to my art. I have used my blog for three classes over three semesters to post images for classes and thoughts pertaining to images and project progress. I will continue to use the blog for posting my own images as well as analyzing works of artists that interest me.

\section{Outcomes of Teaching with Blogs}

Teaching with student blogs provided ease of access to student work and images during class instruction. For example, the instructor could project images of artwork from students' blogs that connected to discussions. Or, students could use images from their blogs to support their arguments in class. At one class meeting a significant portion of students came unprepared. With little disruption the instructor was able to allow students to use a classroom computer or personal device to locate an image and post it to their blog and then continued with the lesson as planned.

The blog assignments permitted students to connect the text content to their research interests and demonstrate application of what they learned. As a result of using the blog two students made direct contact with artists they were researching. Instructors noticed that allowing choice for their final project resulted in students including connections to personal experiences. Some themes students selected included physical and mental health issues, and personal relationships. In prior semesters, students did not overtly include personal connections to their research. Additionally, the weekly assignments forced students to document continual progress on their final projects.

A student survey was conducted during the final class. From the survey we gathered results that support our beliefs: inclusion of the blog was productive for the art criticism course. Eleven of the eighteen students reported that they felt more comfortable using technology and blogs as a result of the course. The remaining seven students indicated no change, or that they were already comfortable with blogs. Sixteen out of eighteen students felt that using the blog to progressively work on the final project over the entire semester was more helpful than working at their own pace. Lastly, we had hoped that students would use the blogs to share their work with each other. To determine if this was accurate, on the survey we asked how often they looked at classmates' blogs. Ten students indicated that they occasionally looked at other students' blogs, six students responded that they frequently looked at classmates' blogs, and two students reported that they never looked at classmates' blogs.

Time was the challenge of teaching art criticism with blogs. We were fortunate to be able to design the course collaboratively. Even with two instructors, grading weekly text and blog assignments was time-consuming. Significant changes would have to be made to the overall 
Danker, Tollefson-Hall, and Newman

amount of assignments and details required for each assignment to feasibly be taught by one instructor.

\section{Conclusions}

Using blogs in an art criticism course allowed students to practice public writing, a necessary skill of the art critic. It provided an avenue for students to share their work, both inside and outside of the classroom setting. Blogs facilitated ongoing student research of contemporary artists and images, and instructors' teaching. Having three options for the final project increased student interest and therefore produced engaging presentations. Students who entered the class reluctant to use a blog or uncertain of their skills left with increased confidence in using technology. 


\section{References}

Barrett, T. (2012). Why is that Art? $2^{\text {nd }}$ ed. New York, NY: Oxford University Press.

Bruff, D. (2011). A social network can be a learning network. The Chronicle of Higher Education.

Buffington, M. (2008). What is Web 2.0 and how can it further art education. Art Education, 61(3), 36-41.

Hernandez-Ramos, P. (2004). Weblogs and online discussion as tools to promote reflective practice. The Journal of Interactive Online Learning, 3(1), 1-16.

Lee, J., \& Young, C. (2010). Building wikis and blogs: Pre-service teacher experiences with web-based collaborative technologies in an interdisciplinary methods course. THEN: Journal. 8 (Winter, 2011). Retrieved April 9, 2012, from http://thenjournal.org/feature/287/.

Luehmann, A., \& MacBride, R. (2008). Classroom blogging in the service of studentcentered pedagogy: Two high school teachers' use of blogs. THEN: Journal, 6 (Summer, 2009). Retrieved April 9, 2012, from http://thenjournal.org/feature/175/.

Miller, W., \& Williams, R. (2013). Preservice teachers and blogs: An invitation to extended reflection and conversation. Art Education, 66(3), 47-52.

Overby, A. (2009). The new conversation: Using weblogs for reflective practice in the studio art classroom. Art Education, 62(4), 18-24.

Rinke, C. R., Stebick, D. M., Schaefer, L., \& Gaffney, M. E. (2009). Using Blogs to Foster Inquiry, Collaboration, and Feedback in Pre-Service Teacher Education. In C. Payne (Ed.), Information Technology and Constructivism in Higher Education: Progressive Learning Framework, (pp. 303-318). Hershey, PA: Information Science Reference. doi:10.4018/978-1 60566-654-9.ch020.

Stiler, G., \& Philleo, T. (2003). Blogging and blogspot: An alternative format for encouraging reflective practice among preservice teachers. Education, 123(4), 789-797.

Teclehaimanot, B., \& Kahle-Piasecki, L. (2010). Web 2.0 in the pre-service teacher classroom: Using blogs to enhance learning. In D. Gibson \& B. Dodge (Eds.), Proceedings of Society for Information Technology \& Teacher Education International Conference 2010, (pp. 2402-2406). Chesapeake, VA: AACE.

Wood, P. (2012). Blogs as liminal space: student teachers at the threshold. Technology, Pedagogy and Education, 21(1), 85-99.

Journal of Teaching and Learning with Technology, Vol. 4, No. 2, December 2015. jotlt.indiana.edu 